\title{
THE DYNAMICS OF THE BRAZILIAN CURRENT ACCOUNT WITH RULE OF THUMB CONSUMERS
}

\author{
Lucio Hellery Holanda Oliveira * \\ Carlos Enrique Carrasco-Gutierrez ${ }^{\dagger} \ddagger$
}

\begin{abstract}
Resumo
O modelo intertemporal tradicional da conta corrente assume que todos os indivíduos seguem a teoria da renda permanente. A inovação proposta neste trabalho é incorporar ao modelo clássico da dinâmica da conta corrente a ideia de que uma parte dos consumidores apresenta comportamento do tipo rule of thumb. São estimadas a parcela da renda agregada que segue o comportamento rule of thumb e o coeficiente de formação de hábitos. Usando os dados de conta corrente para a economia brasileira, os resultados confirmam alguns fatos estilizados apresentados na literatura assim como algumas proposições básicas testáveis do modelo intertemporal da conta corrente.
\end{abstract}

Palavras-chave: Rule of thumb; Consumo; Conta Corrente; Modelo Intertemporal; Formação de Habitos.

\begin{abstract}
The traditional intertemporal current account model assumes that all individuals follow the permanent income theory. The innovation proposed in this work is to incorporate the idea that some consumers have rule of thumb behavior with the classic current account dynamics model. The share of aggregate income that follows the rule of thumb behavior and the habit formation coefficient are estimated. Based on the current account data on the Brazilian economy, the results confirm some stylized facts presented in the literature as well as some testable basic propositions of the intertemporal current account model.
\end{abstract}

Keywords: Rule of Thumb; Consumption; Current Account; Intertemporal Model; Habit Formation.

JEL classification: C22, E21, F32.

DOI: http://dx.doi .org/10.11606/1413-8050/ea138661

\footnotetext{
* Universidade Católica de Brasília - UCB e Analista do Banco Central do Brasil - BCB. E-mail: lucio.holanda@bcb.gov.br.

† Universidade Católica de Brasília - UCB. Programa de Pós-Graduação em Economia. E-mail: carlosgutierrez@ucb.br.

$\ddagger$ As opiniões expressas neste trabalho são exclusivamente dos autores e não refletem, necessariamente, a visão do Banco Central do Brasil
} 


\section{Introduction}

Analysis of current account dynamics has been addressed in several studies since the initial model proposed by Sachs (1981) and subsequently disseminated by Obstfeld \& Rogoff (1996). The ideas that support the permanent income theory, developed by Friedman (1957) and later disseminated by Hall (1978) and Flavin (1981), have been widely applied in intertemporal current account models. An example of the close link between these theories can be seen in the work of Campbell (1987), who developed a new econometric approach to test the permanent income hypothesis. Campbell argued that if consumers actually smooth consumption, saving for bad times when current income is less than permanent income, then declines in wages should be adequately predicted by saving because people rationally expect a decline in future income.

Several studies in the international literature taking the intertemporal approach to the current account followed the paper of Campbell (1987): Sheffrin \& Woo (1990), Otto (1992), Ghosh (1995), Ghosh \& Ostry (1995). Then the model was extended in several directions, particularly emphasizing the role of the variability of interest rates and exchange rates, as in Bergin and Sheffrin (2000); incorporating consumption habits, as in Gruber (2004); adding an exogenous shock in the international interest rate, as per Nason \& Rogers (2006); or constructing a current account model with rule of thumb individuals, as in Pereira (2011).

The inclusion of rule of thumb behavior was originally introduced by Campbell \& Mankiw (1989), who proposed that the permanent income hypothesis is part of a more general model in which only a fraction of disposable income in the economy belongs to consumers who behave according to the permanent income hypothesis. The other fraction belongs to individuals who simply spend all their current income, behavior called rule of thumb. Campbell \& Mankiw demonstrated, using data from the U.S. economy, that about $50 \%$ of disposable income in the country belonged to rule of thumb consumers. Since then, extensive discussion of the importance of rule of thumb behavior in savings has been conducted. Some studies suggest that rule of thumb consumers account for a large portion of disposable income. Cushing (1992) and Weber (2002) investigated whether current income consumption is still important when the concept of nonseparability in time is introduced into the utility function.

Among the works that have studied the behavior of intertemporal current account models supporting the theory of consumption in the Brazilian economy, we can highlight the papers of Senna \& Issler (2000), Silva \& Andrade (2006), Silva \& Andrade (2007) and Oliveira \& Carrasco-Gutierrez (2013). However, no one has introduced rule of thumb in the current account models. In this paper we follow the procedure of Pereira (2011), who introduced in the current account model a fraction of consumers who do not behave according to the permanent income hypothesis. Pereira incorporated rule of thumb behavior in the intertemporal current account model, maintaining the usual assumptions for a small open economy such as exogenously set interest rate, infinitely lived consumers and a single type of risk-free foreign asset. Since rule of thumb consumers do not lend or borrow money, the amount of foreign assets in the economy corresponds to the amount of foreign assets held by permanent income consumers, and the current account standard identity can 
be employed as a restriction to the maximization problem of the representative permanent income consumer. Pereira analyzed data from five countries: South Africa, Australia, Italy, Spain and Turkey. The results pointed to high estimates of the rule of thumb fraction in all economies, ranging from $70 \%$ to $80 \%$, with high significance.

The main contribution of this paper is to test the current account model with rule of thumb consumers using Brazilian economic data. Another important aspect of the theory of consumption is habit formation. It is also included in the estimated current account equation. The idea that rational behavior can be influenced by consumption habits cultivated over time was positively applied to a wide range of issues in economics and was employed by Obstfeld (1992). In this approach, he considers the behavior of consumption with habit formation with the aim of clarifying the interplay of wealth, consumption experience and past and current consumption, and evaluated the processes of external adjustment of an open economy. Here, we also contribute by assessing whether the habit formation estimated from the current account equation is significant for the Brazilian case.

The main results of this paper are twofold. First, the estimation of the parameter associated with rule of thumb consumers suggests that there is a significant portion of these consumers in Brazil. Indeed, about $50 \%$ of consumers follow the rule of thumb type of consumption. Second, regarding social habit formation, our results corroborate those of Cushing (1992), i.e., that consumption of current income is still relevant when the concept of nonseparability in time is introduced in the utility function.

This paper is divided into four sections besides this introduction. Section 2 presets the formal theory underlying the tests dealing with the current account model with rule of thumb consumers. The description of the econometric method for empirical implementation, estimations and results are described in section 3 . The conclusions are presented in section 4 .

\section{Rule of thumb behavior in the intertemporal current account model}

The traditional intertemporal current account model is based on a partial equilibrium structure of a small open economy in which individual decisions do not affect global interest rates and consumption and production decisions can be made independently of one another.

The basic model postulates that a representative household solves an intertemporal maximization problem, choosing a consumption and debt path that maximizes the expected discounted lifetime utility:

$$
U=E_{t}\left[\sum_{i=0}^{\infty} \beta^{i} u\left(C_{t+i}\right)\right]
$$

The consumer is discounting the value of future utility $(0<\beta<1)$ and the marginal utility of private consumption $u^{\prime} C<0$, but decreasing $u^{\prime \prime} C<0$. The next step involves specifying the resource constraint for the economy. At the end of period $t$ the economy produces domestic output $Y_{t}$ and receives income on existing net foreign assets $B_{t}$ with an interest rate $r_{t}$ between periods and $t-1$ and $t$. The received income is spent on private sector consumption $C_{t}$, 
government consumption $G_{t}$, net investment $I_{t}$ and (potentially) acquisition of more foreign assets. Recalling that the current account is defined as the change in net foreign assets, one can write:

$$
C A_{t} \stackrel{\text { def }}{=} B_{t+1}-B_{t} \stackrel{\text { def }}{=} Y_{t}+r \cdot B_{t}-C_{t}-G_{t}-I_{t}
$$

where is defined as the current account at date $t$. When $B_{t}>0$, the country is a creditor in relation to the rest of the world, while when $B_{t}<0$, the country is a debtor. The current account measures the extent of net indebtedness of an economy (borrower or lender) vis-à-vis the rest of the world in a given period, and results from saving and spending decisions. Statistical models that describe the current account simply as a function of exports and imports are not sufficiently clear regarding intertemporal considerations inherent to saving and spending behavior. Thus, the model treats the current account from another perspective, modeling it as a result of the intertemporal prediction behavior of agents and intertemporal choices reflecting the interaction of intertemporal budget constraints and desires.

\subsection{Rule of thumb behavior and habit formation}

The dynamic current account model used in this work incorporates the ideas of rule of thumb consumption and habit formation, according to the method proposed by Pereira (2011). We also assume that consumers have infinite lifetime and only a riskless asset is traded in the international market. Some consumers in this economy behave according to the permanent income theory, adjusting current consumption when a change in permanent income is perceived. Others, however, spend all their current income. Habit formation in the literature is typically modeled by some type of instant non-time-separable utility function, which means that the value derived at present depends not only on the current consumption, but also on the consumption of past periods $^{1}$. Habits are represented by the average rather than the past individual consumption, so consumers believe they are small enough so that their consumption decisions do not affect the average consumption of the economy.

Thus, the theoretical model focuses on the problem of maximizing the utility of permanent income consumers, since the intertemporal budget constraint of those consumers can be expressed using the current account identity and considering the premise that rule of thumb consumers always spend all their current income and, consequently, are always in a net position of zero indebtedness in international terms.

\section{Government}

The government in this small economy taxes income at the constant rate $\tau$, obtaining $\tau Y_{t}$ in taxes and spending $G_{t}$ on goods and services for citizens. It is assumed that the government has a balanced budget over time, i.e. $\tau Y_{t}=G_{t}, \forall t$, $\tau Y_{t}=G_{t}, \forall t$. It is also assumed that government expenditures are perceived as a waste by individuals, not bringing benefits in terms of utility gains.

\footnotetext{
${ }^{1}$ Time separable utility: utility in each period in time depends only on consumption in that period.
} 


\section{Consumption}

We consider an economy populated by two types of consumers with infinite lifetimes. Consumers of the first type behave according to the permanent income hypothesis, smoothing consumption over their lives. The second type is rule of thumb consumers, who spend all their current income at each point in time. Let $Y_{r, t}$ and $Y_{p, t}$ be the income of the rule of thumb group and the permanent income group, respectively. If $\lambda$ is the fraction of domestic income that goes to rule of thumb consumers, then $Y_{r, t}=\lambda Y_{t}$, and $Y_{p, t}=(1-\lambda) Y_{t}$, where $Y_{t}$ is the total domestic income. Also let $C_{r, t}$ and $C_{p, t}$ be the consumption of rule of thumb and permanent income consumers, respectively. Thus, total consumption is given by:

$$
C_{t}=C_{r, t}+C_{p, t}=(1-\tau) \lambda Y_{t}+C_{p, t}
$$

We assume that there is only one asset that can be traded internationally and that the international interest rate is $r$. Following Weber (2002), we also assume there is habit formation for permanent income consumers, so that the current utility depends not only on the current individual consumption, but also on the average past consumption of all consumers. Thus, the permanent income consumer maximizes his expected utility by:

$$
U=E_{t} \sum_{i=0}^{\infty} \beta^{i} u\left(C_{p, t+i}-\phi C_{t+1-1}\right), C_{-1} \text { given }
$$

The term represents the intensity of the habit in the utility function and $\beta$ is the intertemporal discount factor. The utility maximization of the representative agent has the following budget constraint:

$$
-D_{t+i+1}+D_{t+i}=(1-\tau) Y_{p, t+i}-r D_{t+i}-C_{p, t+i}-I_{p, t+i}
$$

where $D_{t}$ represents the indebtedness in terms of the international asset and $I_{p, t}$ is the amount of resources invested in the productive sector. The utility function is represented by a linear-quadratic functional form given by:

$$
u\left(C_{p, t+i}-\phi C_{t+i-1}\right)=\left(C_{p, t+i}-\phi C_{t+i-1}\right)-\frac{h}{2}\left(C_{p, t+i}-\phi C_{t+i}\right)^{2}, h>0
$$

Linear-quadratic utility function specifications have been used in studies in the relevant current account literature, as in the article by Rogoff and Glick \& Rogoff (1995), for example. By assuming $\beta(1+r)=1$, so there is no trend in the consumption trajectory over time, we obtain the following first order condition:

$$
E_{t} C_{p, t+1}-C_{p, t}=\phi\left(C_{t}-C_{t-1}\right)
$$

The (7) states that the change in average consumption would help to predict the consumption of the representative agent. In this model, the result of Hall (1978) random walk applies only when habit formation does not exist, i.e., when $\phi=0$. Let $\eta_{t+1}=C_{p, t+1}-E_{t} C_{p, t+1}$ so as to denote the forecast error in permanent income consumption. Then expression (6) can be rewritten as:

$$
\Delta C_{p, t+1}=\phi \Delta C_{t}+\eta_{t+1}
$$


The condition of transversability to which equation (8) is subject, to remove the possibility of indefinite indebtedness (Ponzi game), is given by expression (8):

$$
\lim _{T \rightarrow \infty}\left(\frac{1}{1+r}\right)^{T} D_{t+T+1}=0
$$

where $D_{t}$ is the foreign currency debt. Since rule of thumb individuals do not save, all investments in the economy are made by permanent income consumers, implying that $I_{p, t+1}=I_{t+1}$. Considering the premise that the government has a balanced budget, the left side of (5) represents the current account:

$$
C A_{t+i}=-D_{t+i+1}+D_{t+i}=Y_{t+i}-r D_{t+i}-C_{t+i}-I_{t+i}-G_{t+i}
$$

By replacing the definition of total consumption given by (3) and rearranging the terms, we get:

$$
C A_{t+i}=(1-\lambda)\left(Y_{t+i}-G_{t+i}\right)-r D_{t+i}-C_{p, t+i}-I_{t+i}
$$

By taking the first differences with $i=0$ and substituting equation (8)in the result, we obtain the following expression for the current account:

$$
C A_{t+1}=(1+r) C A_{t}+(1-\lambda)\left(\Delta Y_{t+1}-\Delta G_{t+1}\right)-\phi \Delta C t-\Delta I_{t+1}+\epsilon_{t+1}
$$

where $\epsilon_{t}=-\eta_{t}$. Marlene, seguem alterações pedidas. Atenciosamente, Editoração FUNDACE Equation (12) relates the current account to its lagged value and to the first differences of aggregate output, government expenditures, aggregate consumption, and aggregate investment. If all these variables are stationary in first differences and the current account is stationary in level, then the equation can be estimated by employing econometric techniques that provide consistent estimates for rule of thumb consumers, $\lambda$, and for the habit formation degree, $\phi$.

\section{Estimations and Results}

\subsection{Strategy}

The method employed in this work is to estimate the parameters of equation (12) of the current account. The estimation of this equation involves two aspects. The first, which is related to the literature on consumption, is the estimation of the parameter $\lambda$ related to consumers' rule of thumb behavior. It is intended to evaluate the empirical evidence related to the share of consumption by rule of thumb agents using a current account for a small open economy. The second aspect is related to the current account literature. Estimating equation (12) allows evaluation of the quality of the model in terms of replicating the behavior of current account dynamics. In line with the work of Sheffrin \& Woo (1990), Ghosh (1995), Ghosh \& Ostry (1995) in the case of international economies, and Senna \& Issler (2000) for the Brazilian economy, it is possible to compare the actual current account series with the series predicted by the model. The similarity between the behaviors of these two series can provide an idea of the level of model fit. In order to perform the econometric tests in this paper, we used a rearranged form of equation (12): 


$$
C A_{t+1}-(1+r) C A_{t}+\Delta I_{t+1}=(1-\lambda)\left(\Delta Y_{t+1}-\Delta G_{t+1}\right)-\phi \Delta C_{t}+\epsilon_{t+1}
$$

Since the estimation of the interest rate $r$ as a coefficient can be particularly problematic, we follow the usual practice to arbitrate its values, which leads us to a time series on the left side of equation (13). An important aspect of the estimation of equation (13) is that the error $\epsilon_{t}$, which is related to the permanent income consumption forecast error, $\eta_{t+1}=C_{p, t+1}-E_{t} C_{p, t+1}$, which cannot be orthogonal to the income variation. Supposing an unexpected increase in current income from $t$ to $t+1$ the greater the increase in current income, the greater will be the impact on permanent income, the greater the increase in consumption at $t+1$ and the greater the permanent income consumption forecast error in $t$. Consequently, the error term in equation (13) will be correlated with the regressors, and estimation via ordinary least squares (OLS) would not produce consistent estimates of the parameters. The estimation of equation (13) is performed employing instrumental variables (2-SLS) and generalized method of moments (GMM). The chosen instruments are combinations of lagged values of the explanatory variables. From this procedure, the estimated values of $\lambda$ and $\phi$ are obtained. In relation to income taxation, the estimation of $\tau$ is based on government's balanced budget, so it is possible to obtain a consistent estimator of $\tau$ via OLS estimation of:

$$
\Delta G_{t}=\tau \Delta Y_{t}+v_{t}
$$

where $v_{t}$ is an i.i.d process.

\subsection{Data}

We used annual data for the Brazilian economy from the period 1947 to 2010 . The data on aggregated consumption, government expenditures, aggregated investment and aggregated output were obtained from the Ipeadata database and the data source is the Instituto Brasileiro de Geografia e Estatistica - IBGE (Brazilian Institute of Geography and Statistics). All values were converted into constant prices through the implicit GDP deflator, using the year 2010 as base and then transformed to per capita values. We used the following series: household consumption; final government consumption, gross fixed capital formation, gross domestic product, and property income sent to and received from the rest of the world. All these series are available in Brazilian currency ( $\mathrm{R} \$$ million). All values were converted to constant prices of a reference period through the implicit GDP deflator, taking the year 2010 as base. For this purpose, we used the gross domestic product (GDP) series - implicit deflator: annual variation. Finally, the series were converted to per capita values employing the resident population series - total. Since the population series is only available every 10 years (national census), we applied interpolation to obtain population data with annual basis. The actual current account series was calculated using the equation:

$$
C A_{t} \stackrel{\text { def }}{=} y_{t}+r . b_{t}-c_{t}-g_{t}-i_{t}
$$

where $r$ is the interest rate, which is deemed fixed, so that $r . b_{t}$ is the net return on factors, which consists of interest and dividends earned on net foreign 
assets, $y$ is the GDP, $i$ is the aggregate investment and $g$ is the level of government expenditures, assuming the government budget is always balanced.

\subsection{Unit root test}

Observing the expression (12), which relates the current account value to its lagged value and with first differences of aggregate output, government expenditures, aggregate consumption and aggregate investment, it can be seen that in order to obtain consistent estimators for $\lambda$ and $\phi$, respectively, the share of rule of thumb consumers and the degree of habit formation, it is necessary that both current account and explanatory variables, that appear on the right side of that expression be stationary. Moreover, if a unit root is present in any of the variables in expression (12), the use of the instrumental variables method to estimate the model could lead to spurious results. So, as usual, we performed initial tests to check for the presence of unit roots in the series employed in the model. Table 1 presents the results for augmented DickeyFuller $(A D F)$, augmented Dickey-Fuller with GLS $\left(A D F_{G L S}\right)$, Phillips-Perron $(P P)$, and Kwiatkowski-Phillips-Schmidt-Shin (KPSS) tests for level variables and in first difference. The test results indicate that the null hypothesis of existence of unit root can be accepted for the series at the level of aggregate consumption $c_{t}$, government expenditures $g_{t}$, aggregate investment $i_{t}$, and aggregate output $y_{t}$. The tests also show that one cannot accept the null hypothesis for the series in the current account $c a_{t}$ level, which is in agreement with what is predicted by the theory about the stationarity of the series. For the data series in first differences, the results suggest that the null hypothesis of the presence of unit root cannot be accepted at a significance level of $5 \%$ in all cases. Thus, based on the results presented in Table 1, we assume that the current account is stationary and that consumption, government expenditures, investment and product have a unit root or, alternatively, are order-one integrated.

Table 1: Unit root test of the series ${ }^{1}$

\begin{tabular}{lllll}
\hline Variable & $\begin{array}{l}\text { ADF Test } \\
\text { Statistic }\end{array}$ & $\begin{array}{l}\mathrm{ADF}^{G L S} \text { Test }^{3} t- \\
\text { Statistic }\end{array}$ & $\begin{array}{l}\text { PP Test } \\
\text { Statistic }\end{array}$ & $\begin{array}{l}\text { KPSS }^{5} \\
t \text {-Statistic }\end{array}$ \\
\hline$c a_{t}$ & $-2.9795^{* *}$ & $-2.9449^{* * *}$ & $-2.9795^{* *}$ & 0.2635 \\
$c_{t}$ & -0.5710 & 0.4898 & -0.6269 & $0.9484^{* * *}$ \\
$\Delta c_{t}$ & $-3.0217^{* *}$ & $-1.9986^{* *}$ & $-6.4247^{* * *}$ & 0.0888 \\
$g_{t}$ & 1.3884 & .0261 & $1.4963^{* * *}$ & $0.9756^{* * *}$ \\
$\Delta g_{t}$ & $-7.0293^{* * *}$ & $-7.0850^{* * *}$ & $-7.0341^{* * *}$ & $0.3866^{*}$ \\
$i_{t}$ & -1.0627 & -0.0381 & -0.9717 & $0.8363^{* * *}$ \\
$\Delta i_{t}$ & $-6.7824^{* * *}$ & $-6.7928^{* * *}$ & $-6.6869^{* * *}$ & 0.1018 \\
$y_{t}$ & -0.2562 & 0.9503 & -0.1929 & $0.9877^{* * *}$ \\
$\Delta y_{t}$ & $-3.7348^{* * *}$ & $-3.7441^{* * *}$ & $-5.6806^{* * *}$ & 0.0858 \\
\hline
\end{tabular}

\footnotetext{
${ }^{1}$ Applied to test equations with intercept. Significance of $1 \%, 5 \%$ and $10 \%$ are represented by ${ }^{* * *},{ }^{* *}$ and ${ }^{*}$, respectively.

2 and ${ }^{3}$ We used the modified Akaike information criterion with automatic selection to obtain the optimal lag.

${ }^{3}$ Critical values: $-2.6022(1 \%),-1.9461(5 \%)-1.6134$ (10\%).

${ }^{4}$ We used the estimation method of Newey-West with Bartlett kernel for bandwidth.

${ }^{5}$ The KPSS test has the null hypothesis of stationarity of the series. Critical values: $0.7390(1 \%), 0.4630(5 \%)$ and $0.3470(10 \%)$.
} 


\subsection{Estimation of the current account equation}

For current account estimation, we used two-stage least squares and generalized method of moments. The use of lagged values of the macroeconomic variables as instruments is a procedure commonly adopted in the literature. The instruments employed in this work were the lagged values of the first differences of aggregate output $Y$, aggregate investment $I$, aggregate consumption $C$ and government expenditures $G$. Table 2 in Appendix Appendix A presents the 23 groups of instruments used in the estimates. The definition of groups of instruments was preceded by regression of the series $\Delta Y_{t}-\Delta G_{t}$, correlated with the error, using ordinary least squares (OLS) and using as regressors a single, and up to two lags of the explanatory variables. The estimation results are shown in Table 2, allowing evaluation of the potential instruments. It can be observed that the first differences of the product $Y$ and the investment $I$, lagged one period, appear to be important instruments, since they are significant at $1 \%$ in the two estimates. For this reason, at least one of these two variables is present in the groups of instruments. It can also be seen that the F-statistic in regressions with one or two lags is significant at $1 \%$ and $5 \%$, respectively, which confirms the existence of relevant explanatory variables in the regressions.

Table 2: $\Delta Y_{t}-\Delta G_{T}$ series estimation via OLS for instruments selection

\begin{tabular}{lccccc}
\hline Regressors & Coefficient & 1 lag & p-value & 1 to 2 lags & p-value \\
\hline$\Delta Y_{t-1}$ & $\alpha_{1}$ & 0.515337 & 0.0045 & 0.547640 & 0.0044 \\
$\Delta Y_{t-2}$ & $\alpha_{5}$ & - & - & 0.214046 & 1.3238 \\
$\Delta G_{t-1}$ & $\alpha_{2}$ & -0.322506 & 0.4047 & -0.491214 & 0.3362 \\
$\Delta G_{t-2}$ & $\alpha_{6}$ & - & - & -0.659767 & 0.1168 \\
$\Delta I_{t-1}$ & $\alpha_{3}$ & -0.880971 & 0.0017 & -1.128858 & 0.0003 \\
$\Delta I_{t-2}$ & $\alpha_{7}$ & - & - & 0.017034 & 0.9681 \\
$\Delta C_{t-2}$ & $\alpha_{4}$ & 0.265831 & 0.0787 & 0.116625 & 0.6681 \\
$\Delta C_{t-3}$ & $\alpha_{8}$ & - & - & 0.164753 & 0.3037 \\
$R^{2}$ & - & 0.220839 & - & 0.290654 & - \\
$R^{2}$ adjusted & - & 0.165185 & - & 0.179383 & - \\
F statistics & - & 3.968044 & 0.006636 & 2.612145 & 0.017782 \\
\hline Notes: 1 lag: $\Delta Y_{t}-\Delta G_{t}=\alpha_{1} \Delta Y_{t-1}+\alpha_{2} \Delta G_{t-1}+\alpha_{3} \Delta I_{t-1}+\alpha_{4} \Delta C_{t-2}$ \\
up to 2 lags: $\Delta Y_{t}-\Delta G_{t}=\alpha_{1} \Delta Y_{t-1}+\alpha_{2} \Delta G_{t-1}+\alpha_{3} \Delta I_{t-1}+\alpha_{4} \Delta C_{t-2}+$ \\
$\alpha_{5} \Delta Y_{t-2}+\alpha_{6} \Delta G_{t-2}+\alpha_{7} \Delta I_{t-2}+\alpha_{8} \Delta C_{t-3}$ & & \\
\end{tabular}

Regarding the interest rate $r$ used in the model, the estimates were made considering annual values of $2 \%, 4 \%$ and $8 \%{ }^{2}$, rates that are of the same magnitude as commonly adopted in studies that seek to verify empirical evidence of the intertemporal current account model using data from the Brazilian economy, such as Senna \& Issler $(2000)^{3}$ and Silva \& Andrade (2006). Figure 1 shows the evolution of some international interest rates in recent decades, which seems to confirm that a range $2-8 \%$ covers most of the period studied, except the years of crisis in the late 1970s and beginning of the 80 s.

The results for estimating the parameters $(1-\lambda)$ and $\phi$ from equation (13) are shown in Table 3. The full results of estimations with 2SLS and

\footnotetext{
${ }^{2}$ According to Otto (1992), the use of an interest rate in the range between $2 \%$ and $8 \%$ does not significantly affect the test results.

${ }^{3}$ Senna \& Issler (2000) report they used interest rate values between $0 \%$ and $6 \%$ and found that the change of the magnitude of the results was irrelevant.
} 


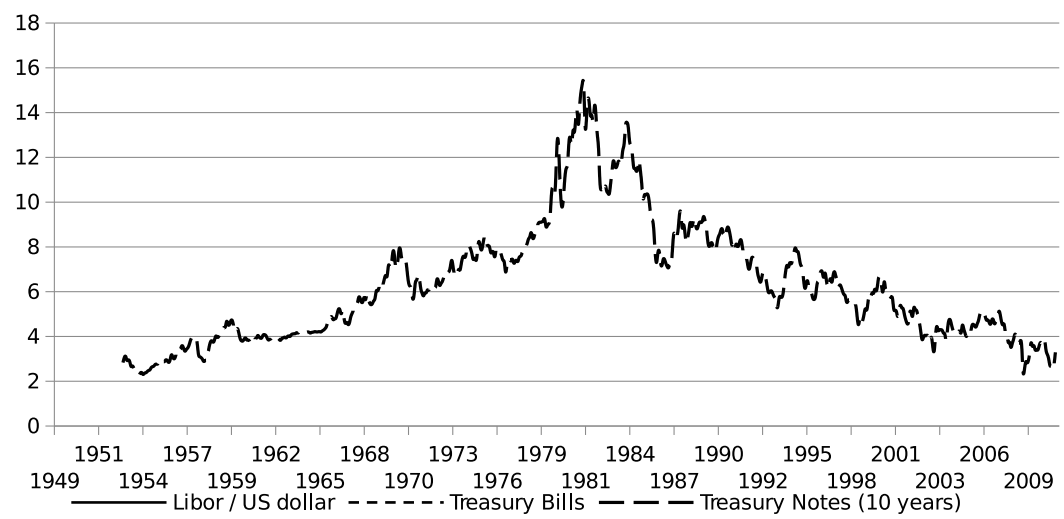

${ }^{1}$ Source: Ipeadata

${ }^{2}$ LIBOR/US dollar is the average rate at which a representative group of banks in London give each other loans denominated in US dollars. Data available from 1971 to 2009.

3 Treasury Bills are U.S. Government securities with maturities ranging from several days to 52 weeks. Data available from 1948 to 2010.

4 Treasury Notes are U.S. Government securities issued with maturities of 2, 3, 5, 7 and 10 years. Data available from 1953 to 2010.

\section{Figure 1: International interest rates}

GMM are presented in Appendix Appendix B. For estimation via GMM, we employed three methods for selecting bandwidth: Newey-West fixed, NeweyWest variable and Andrews. The parameter $(1-\lambda)$ represents the fraction of the economy in which consumers behave according to the permanent income theory. To generate the statistics in Table 4, we used the groups of instruments which resulted in a significant estimation $(10 \%$ level) both in relation to the J-statistic, which is an indicator of the level of endogeneity of the instruments, and in relation to parameters $(1-\lambda)$ and $\phi$. Regarding the J-statistic, only the model corresponding to group 15 of instruments was rejected $\left(\Delta Y_{t}, \Delta G_{t}\right)$, with Newey-West fixed and 2SLS for the three interest rates assessed. Using these criteria for the calculation of average values and for the selection of minimum and maximum values, the average values for the estimated parameter varied between 0.4501 and 0.5110 in the estimate with 2SLS, and between 0.4638 and 0.5239 in the estimate via GMM. Thus, these results indicate that about $50 \%$ of consumers have rule of thumb consumption when the dynamics of the Brazilian economy is evaluated from the perspective of the current account.

Another important aspect is that the results show that the model has little sensitivity to interest rates. Comparing the results obtained with the rates of $2 \%$ and $8 \%$, there is only a slight increase in the estimated average parameter, which was $14 \%$ with 2 SLS, $8 \%$ with GMM - Newey-West fixed, $7 \%$ with GMM - Newey-West variable and 10\% with GMM - Andrews. Table 4 summarizes the previous results that rule of thumb behavior is relevant when assessing the consumption decisions of the representative Brazilian household. In this work, considering the current account intertemporal setup, we also evidenced that the rule of thumb behavior is significant. The range of values obtained run from 0.40 to 0.54 , which are close to the estimates of Gesteira \& CarrascoGutierrez (2015) but below those of other authors, except for the results from the work of Cavalcanti (1993).

With respect to the parameter $\phi$, which represents the degree of social 
Table 3: Estimation of the parameter $(1-\lambda)$ of equation (12) - Summary

\begin{tabular}{lcccccccccc}
\hline Interest rates & \multicolumn{3}{c}{$2 \%$} & & & $4 \%$ & & & $8 \%$ \\
\hline & average & $\min$ & $\max$ & average & $\min$ & $\max$ & average & $\min$ & $\max$ \\
Parameter $(1-\lambda)$ & & & & & & & & & & \\
GMM $^{(1)}$ & & & & & & & & & \\
Newey-West Fixed & $\mathbf{0 . 4 6 3 8}$ & 0.3187 & 0.9014 & 0.4800 & 0.3387 & 0.9123 & 0.4996 & 0.2960 & 0.9335 \\
Newey-West Variable & 0.4876 & 0.2525 & 1.0107 & 0.4985 & 0.2701 & 1.0157 & $\mathbf{0 . 5 2 3 9}$ & 0.3091 & 1.0260 \\
Andrews & 0.4724 & 0.3292 & 0.9574 & 0.4891 & 0.3499 & 0.9663 & 0.5195 & 0.3919 & 0.9829 \\
2SLS & $\mathbf{0 . 4 5 0 1}$ & 0.3131 & 0.7578 & 0.4669 & 0.3292 & 0.7703 & $\mathbf{0 . 5 1 1 0}$ & 0.3615 & 0.7952 \\
Parameter $\phi^{(2)}$ & & & & & & & & & & \\
GMM & & & & & & & & & \\
Newey-West Fixed & $(3)$ & $\mathbf{0 . 4 2 8 7}$ & 1.0062 & $(3)$ & 0.4334 & 1.0031 & $(3)$ & 0.4400 & 0.9961 \\
Newey-West Variable & $(4)$ & 0.7350 & $\mathbf{1 . 0 9 7 1}$ & $(4)$ & 0.7376 & 1.0873 & $(4)$ & 0.7374 & 1.0698 \\
Andrews & $(2)$ & 0.9649 & 1.0647 & $(2)$ & 0.9685 & 1.0595 & $(2)$ & 0.9739 & 1.0476 \\
2SLS & 0 & - & - & 0 & - & - & 0 & - & - \\
\hline
\end{tabular}

${ }^{1}$ Lowest and highest average values estimated by GMM and 2SLS are highlighted.

2 The numbers in parentheses represent the number of valid instruments in the case of the parameter estimates $\phi$

${ }^{3}$ Lowest and highest values estimated by GMM are highlighted.

Table 4: Results in the literature for the estimation of rule of thumb in the Brazilian economy

\begin{tabular}{|c|c|c|}
\hline Authors & Period studied & Parameter $\lambda$ \\
\hline & Theory of consumption & \\
\hline Cavalcanti (1993) & 1980 to $1989^{\circ}$ & 0.32 \\
\hline Reis et al. (1998) & 1947 to 1994 & 0.80 \\
\hline Issler \& Rocha (2000) & 1947 to 1994 & 0.74 \\
\hline Gomes (2004) & 1947 to 1999 & 0.85 \\
\hline Gomes \& Paz (2004) & 1951 to 2000 & 0.61 \\
\hline Gomes (2010) & 1950 to 2003 & $\begin{array}{c}{[0.83,0.91] I P A} \\
{[0.73,1.06] I G P-D I}\end{array}$ \\
\hline Gesteira \& Carrasco-Gutierrez (2015) & 1950 to 2010 & {$[0.72,0.85]$} \\
\hline & $\begin{array}{l}\text { Current account model } \\
\text { with rule of thumb }\end{array}$ & \\
\hline Present work & 1947 to 2010 & {$[0.48,0.54]^{1}$} \\
\hline
\end{tabular}

habit formation, the estimated values ranged from 0.428 to 1.097 , with little sensitivity to changes in interest rates. For the sake of comparison to the values obtained in this work, Gruber (2004) added consumption habits to the standard intertemporal current account and obtained a value close to 0.80 . Table 5 shows the values of the parameter $\phi$ with $10 \%$ significance. The results were the same for the different interest rates employed. It appears that only the instrument groups 16 and 22 had significant estimates for the three GMM configurations: Newey-West fixed, Newey-West variable and Andrews. Furthermore, we found no valid instrument group when the 2SLS technique was used.

\subsection{Estimation of the taxation parameter $\tau$}

Figure 2 shows the changes in government expenditures $\Delta G_{t}$ due to the variation in product $\Delta Y_{t}$. In the first quadrant, there are 39 occurrences, representing $62 \%$ of the sample. Thus, it can be seen that as a rule, the increase in output is associated with an increase in expenditure due to the higher density 
Table 5: Estimates of at $10 \%$ significance by group of instruments ${ }^{1}$

\begin{tabular}{llcccc}
\hline Group & Instruments & $\begin{array}{c}\text { GMM - Newey-West } \\
\text { Fixed }\end{array}$ & $\begin{array}{c}\text { GMM - Newey-West } \\
\text { Variable }\end{array}$ & $\begin{array}{c}\text { GMM - } \\
\text { Andrews }\end{array}$ & TSLS \\
\hline 15 & $\Delta Y_{t}, \Delta G_{t}$ & & $\mathrm{x}$ & \\
16 & $\Delta I_{t}, \Delta G_{t}$ & $\mathrm{x}$ & $\mathrm{x}$ & $\mathrm{x}$ \\
21 & $\Delta Y_{t}, \Delta G_{t}, \Delta C_{t-1}$ & $\mathrm{x}$ & $\mathrm{x}$ & $\mathrm{x}$ \\
22 & $\Delta I_{t}, \Delta G_{t}, \Delta C_{t-1}$ & $\mathrm{x}$ & & \\
23 & $\Delta Y_{t}, \Delta I_{t}, \Delta G_{t}, \Delta C_{t-1}$ & $\mathrm{x}$ & & \\
\hline
\end{tabular}

${ }^{1}$ Groups of instruments that do not result in any significant estimation when at least $10 \%$ are omitted from the table.

of occurrences in the first quadrant, where the variations of the two series are positive.

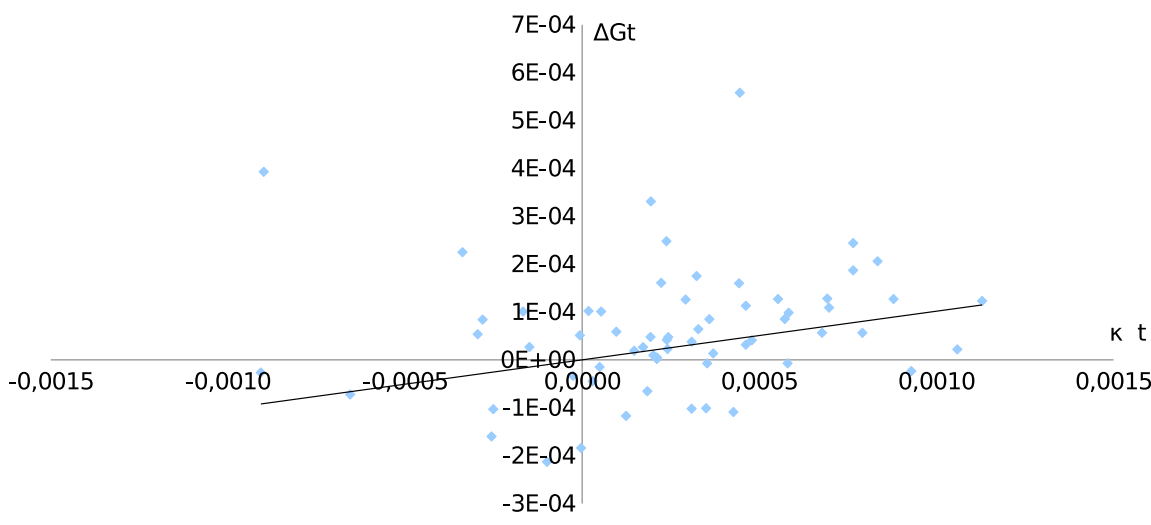

Figure 2: Government expenditure variation versus product variation

For estimation of the parameter $\tau$, which gives information about the tax burden in the economy, we performed OLS regression of equation (14). The results are shown in Table 6. It can be noted that a value on the order of 0.10 was found and it is significant at $1 \%$. The $R^{2}$ value is 0.12 . This low value is noteworthy, indicating a weak linear correlation between the variation in expenditure and the variation in product.

Table 6: Tax equation estimation via OLS $\left(\Delta G_{t}=\tau \Delta Y_{t}+v_{t}\right)$

\begin{tabular}{lcccc}
\hline Parameter & Estimation & $t$ statistic & p-value & $R^{2}=\left[\operatorname{Corr}\left(\Delta G_{t}, \Delta Y_{t}\right)\right]^{2}$ \\
\hline$\tau$ & 0.1017 & 2.8778 & 0.0055 & -0.0683 \\
\hline
\end{tabular}

To verify if the model is well adjusted, we carried out autocorrelation and heteroscedasticity tests of the regression residuals. The Breusch-Godfrey LM test was employed to assess the presence of autocorrelation. We obtained an Fstatistic of 0.4961 and a p-value of 0.6114 , thus the null hypothesis of no serial 
correlation was accepted. With regard to heteroscedasticity, we performed the Breusch-Pagan-Godfrey test, resulting in an F-statistic of 3.4344 and a pvalue of 0.0687 , which therefore allows accepting the null hypothesis of no heteroscedasticity, but only at $10 \%$ significance.

\subsection{Evaluation of the estimated series for the current account}

One way to assess how well the theoretical model employed in this work describes the dynamics of the current account is to compare the estimated current account curve with the actual curve. To this end, we compared the values estimated from equation (13) for the term $C A_{t+1}-(1+r) C A_{t}+\Delta I_{t+1}$.

Figure 3 shows the estimated values for this dependent variable, using an interest rate of $2 \%$, considering the estimate for $(1-\lambda)$ and $\phi$ employing instrumental variables with GMM and instruments group 1. It can be observed that the dependent variables' actual series and estimated series are relatively close.

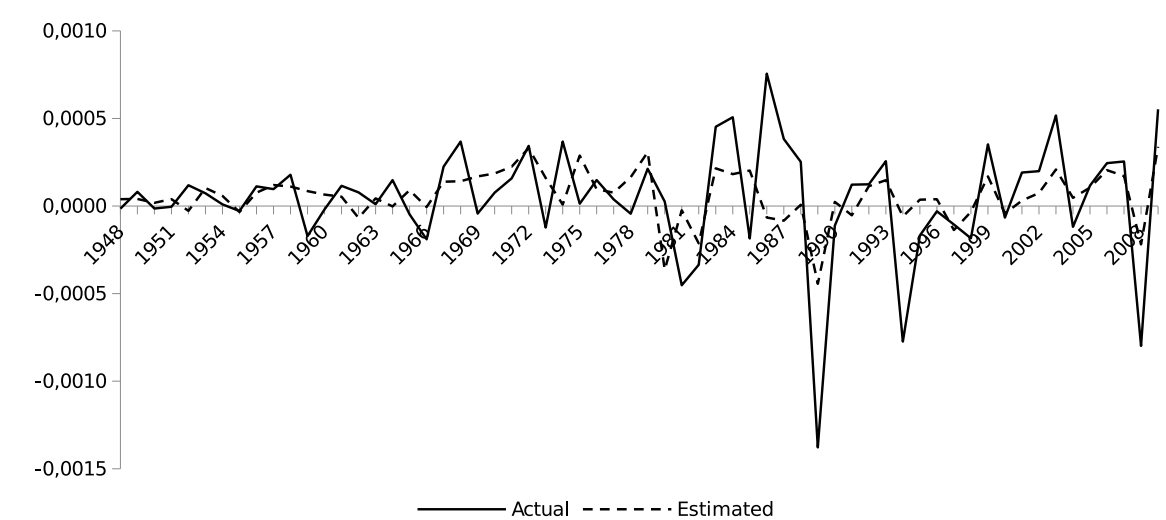

${ }^{1}$ The Newey-West fixed bandwidth selection method was used in the GMM estimation.

Figure 3: Government expenditure variation versus product variation

Another important evaluation can be performed using the estimated current account series from equation (12), with values of $(1-\lambda)$ and $\phi$, obtained in the estimation of the current account equation with instrumental variables and GMM with interest rate of $2 \%$. For this purpose, since the left side of equation (12), which describes the estimated current account at time $t+1$, depends on the value of the current account in the previous period $t$, it is necessary to establish an initial value for the variable and then to perform successive iterations of the values obtained in the immediately preceding step. For the initial value of the estimated current account, $C A_{t}^{e}$ and $t=1947$, we employed the actual current account value in that year, obtained from expression (16), where $b_{t+1}$ denotes the value of foreign assets of the economy at the end of period $t$ and where the current account is defined as (Obstfeld \& Rogoff 1996):

$$
C A_{t} \stackrel{\text { def }}{=} b_{t+1}-b_{t} \stackrel{\text { def }}{=} y_{t}+r \cdot b_{t}-c_{t}-g_{t}-i_{t}
$$

where $r$ is the interest rate and is assumed fixed, so that net return on factors is $r . b_{t}$, which consists of interest and dividends earned on net foreign assets, $y_{t}$ is 
gross domestic product (GDP); it is the level of investment at end of period $t$; and $g_{t}$ is the level of government expenditures, assuming that the government budget is always balanced.

The results for the estimated series via iteration are shown in Figure 4, including the actual current account curve obtained from equation (15) and the optimal estimated current account from the econometric technique developed by Campbell \& Schiller (1987), whose method consists of estimating a vector autoregressive (VAR) model to predict the optimal behavior of current account, and then using the VAR coefficients to construct the optimal current account series.

It can be noted that the estimated series from expression (12), which incorporates the concepts of the rule of thumb consumption and habit formation, is reasonably close to the real series for the indicted period. Evaluation of the three curves shows that the estimated values via our method deviate from the real and optimal series in the early 1970s and for much of the 1990s. It can also be noted that in a few years of the 1980s and 1990s, the estimated series presents a range of variation wider than the other two series. Hence, the model presented greater sensitivity for these periods.

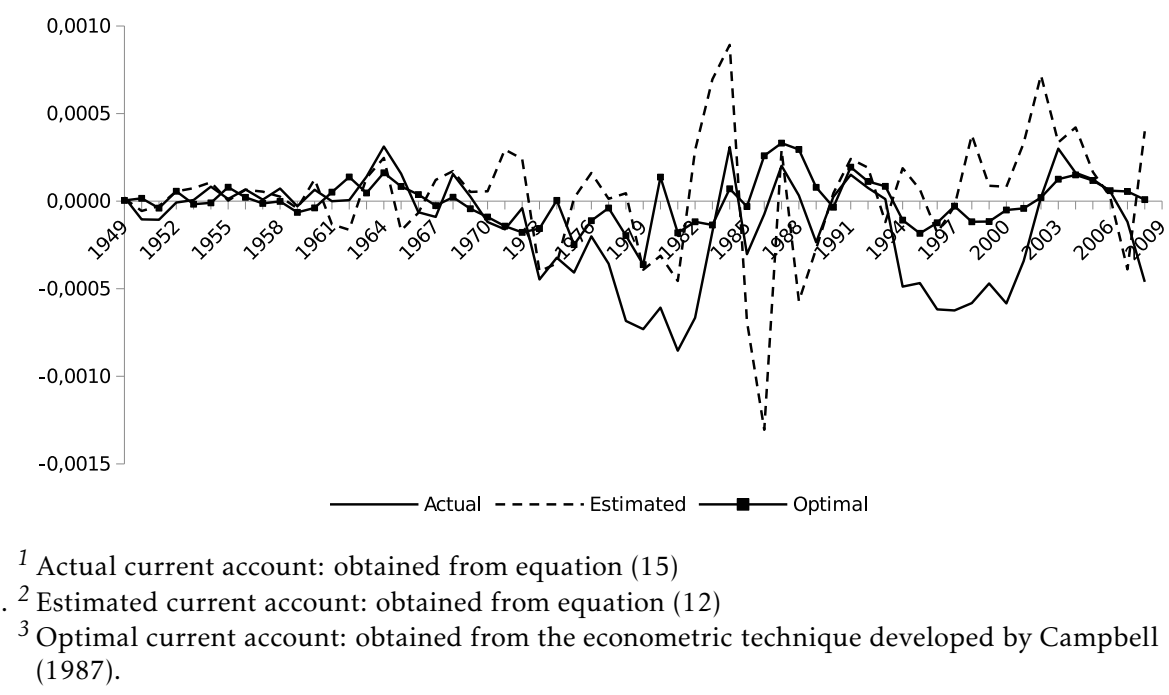

Figure 4: Actual current account, estimated current account considering rule of thumb consumption and optimal current account

Table 7 presents the standard deviations of the three current account series. With respect to the series' volatility, the data suggest that the estimated current account in this study, $C A_{t}^{e}$, which considers consumers with rule of thumb behavior, is more volatile than the actual current account $C A_{t}$, and the optimal current account series $C A_{t}^{*}$, which consider that all consumers fully smooth their consumption. Regarding the correlation between the estimated series and the actual series presented in Table 8 , the value of 0.25 is below the correlation obtained with the optimal series not improving the model's performance in this specific case. 
Table 7: Standard deviations of the estimated current account series $C A_{t}^{e}$, the optimal series $C A_{t}^{*}$ and the actual current account series $C A_{t}$

\begin{tabular}{ccccc}
\hline$S D\left(C A_{t}^{e}\right)$ & $S D\left(C A_{t}\right)$ & $S D\left(C A_{t}^{*}\right)$ & $\frac{S D\left(C A_{t}^{e}\right)}{S D\left(C A_{t}\right)}$ & $\frac{S D\left(C A_{t}^{*}\right)}{S D\left(C A_{t}\right)}$ \\
\hline 0.000332 & 0.000285 & 0.000127 & 1.17 & 0.44 \\
\hline
\end{tabular}

Table 8: Correlation between the estimated current account series $C A_{t}^{e}$, the optimal series $C A_{t}^{*}$ and the actual current account series $C A_{t}$

\begin{tabular}{lc}
\hline $\operatorname{Corr}\left(C A_{t}^{e}, C A_{t}\right)$ & $\operatorname{Corr}\left(C A_{t}^{*}, C A_{t}\right)$ \\
\hline 0.253601 & 0.644419 \\
\hline
\end{tabular}

\section{Conclusions}

This paper applies an econometric technique to test the intertemporal current account model in the Brazilian economy for the period 1947 to 2010. The innovation proposed in this model is to incorporate the idea that consumers have rule of thumb behavior to the classic current account dynamics model, and also to include habit formation in the utility function. The estimation of the current account model employed the two-stage least squares (2SLS) and generalized method of moments (GMM) econometric techniques. The results confirm some stylized facts in the literature and some basic testable propositions of the intertemporal current account model. Rule of thumb behavior is significant and ranges from 0.48 to 0.54 . These estimates are close to the range of values obtained in the literature on consumption decisions of the representative Brazilian household. It should be noted that this type of consumer behavior can still be associated with difficulties in accessing the banking sector, which could prevent consumers from smoothing their consumption through saving or credit. Regarding social habit formation, the study confirmed the result obtained by Cushing (1992) that consumption of current income is still relevant when the concept of nonseparability in time is introduced in the utility function. The estimated value for the degree of habit formation ranges from 0.43 to 1.10 .

Another important result was the finding that the estimates of both the parameter and the degree of habit formation showed little sensitivity to interest rate changes, as already shown in other works in the literature on current account dynamics. In estimating the degree of taxation of the economy, we found a value of around $10 \%$, although we did not identify a significant linear correlation between the change in government expenditure and output variation. The series which was estimated from the expression incorporating the rule of thumb consumption and habit formation concepts was compared to the actual series and the optimal current account series. The latter was ob- 
tained from the strategy used by Campbell \& Schiller (1987) to estimate the optimal behavior of the current account. The comparison indicated that the curve estimated with the inclusion of rule of thumb consumer is consistent with the other two, though there is departure of the estimated curve from the other two in some years of the 1970s and 1990s. The curve presented an estimated standard deviation larger than that of the actual curve, suggesting higher volatility. Furthermore, the correlation between the estimated curve and actual curve was lower than the value obtained when the optimal and actual series were taken into consideration.

For future work, we suggest observation of the behavior of the model when different values for the degree of habit formation are set. It would also be interesting to assess the performance of the model as a predictor of current account at other interest rates and with other groups of instruments.

\section{Bibliography}

Campbell, J. Y. (1987), 'Does saving anticipate declining labor income? an alternative test of the permanent income hypothesis', Econometrica 55(6), 1249-1273.

Campbell, J. Y. \& Mankiw, G. (1989), Consumption, income, and interest rates: Reinterpreting the time series evidence, in $\mathrm{O}$. Blanchard \& $\mathrm{S}$. Fisher, eds, 'Macroeconomics Annual', NBER, p. 185-214.

Campbell, J. Y. \& Schiller, R. J. (1987), 'Cointegration and tests of present value models', Journal of Political Economy 95(5), 1062-1088.

Cavalcanti, C. B. (1993), 'Intertemporal substitution in consumption: An empirical investigation for brazil', Brazilian Review of Econometrics 13(2), 203-229.

Cushing, M. (1992), 'Liquidity constraints and aggregate consumption behavior', Economic Inquiry 30, 134-153.

Flavin, M. A. (1981), 'The adjustment of consumption to changing expectations about future income', Journal of Political Economy 89, 974-1009.

Friedman, M. (1957), A theory of the consumption function, Princeton University Press.

Gesteira, M. \& Carrasco-Gutierrez, C. (2015), 'Testing the optimality of consumption decisions of the representative household: Evidence from brazil', Revista Brasileira de Economia 69(3), 373-387.

Ghosh, A. R. (1995), 'International capital mobility amongst the major industrialized countries: too little or too much?', The Economic Journal 105(428), 107-128.

Ghosh, A. R. \& Ostry, J. D. (1995), 'The current account in developing countries: A perspective from the consumption-smoothing approach', World Bank Economic Review 9(2), 305-333.

Glick, R. \& Rogoff, K. (1995), 'Global versus country-specific productivity shocks and the current account', Journal of Monetary Economics 35, 159-192. 
Gomes, F. A. R. (2004), 'Consumo no brasil: teoria da renda permanente, formação de hábito e restrição à liquidez', Revista Brasileira de Economia 58(3), 381-402.

Gomes, F. A. R. (2010), 'Consumo no brasil: Comportamento otimizador, restrição de crédito ou miopia?', Revista Brasileira de Economia 64(3), 381402.

Gomes, F. A. R. \& Paz, L. S. (2004), 'Especificações para a função consumo: Testes para países da américa do sul', Pesquisa e Planejamento Econômico 34(1), 39-55.

Gruber, J. W. (2004), 'A present value test of habits and the current account', Journal of Monetary Economics 51, 1495-1507.

Hall, R. E. (1978), 'Stochastic implications of the life cycle-permanent income hypothesis: theory and evidence', Journal of Political Economy 86(6), 971-987.

Issler, J. V. \& Rocha, F. P. (2000), 'Consumo, restrição à liquidez e bem-estar no brasil', Economia Aplicada 4(4), 637-665.

Nason, J. M. \& Rogers, J. H. (2006), 'The present-value model of the current account has been rejected: Round up the usual suspects', Journal of International Economics 68, 159-187.

Obstfeld, M. (1992), 'International adjustment with habit-forming consumption: A diagrammatic exposition', Review of International Economics 1, 32-48.

Obstfeld, M. \& Rogoff, K. (1996), Foundations of international macroeconomics, The MIT Press, Cambridge, Massachusetts.

Oliveira, L. H. H. \& Carrasco-Gutierrez, C. E. (2013), 'Testando as implicações do modelo intertemporal da conta-corrente para o brasil: 1947- 2010', Análise Econômica 31(59).

Otto, G. (1992), 'Testing a present-value model of the current account: evidence from us and canadian time series', Journal of International Money and Finance 11(5), 414-430.

Pereira, R. M. (2011), 'Current account dynamics with rule of thumb consumers', Revista Brasileira de Economia .

Reis, E., Issler, J. V., Blanco, F. \& Carvalho, L. (1998), 'Renda permanente e poupança precaucional: Evidências empíricas para o brasil no passado recente', Pesquisa e Planejamento Econômico 28(2), 233-272.

Sachs, J. (1981), 'The current account and macroeconomic adjustment in the 1970's', Brooking Papers Econ. Activity 1, 201-268.

Senna, F. A. d. A. \& Issler, J. V. (2000), 'Mobilidade de capitais e movimentos da conta corrente do brasil: 1947-1997', Estudos Econômicos 30(4), 493-523.

Sheffrin, S. M. \& Woo, W. T. (1990), 'Present value tests of an intertemporal model of the current account', Journal of International Economics 29(34), 237-253. 
Silva, N. \& Andrade, J. P. d. (2006), 'Dinâmica das transações correntes do brasil: Avaliação do modelo básico da abordagem intertemporal', Pesquisa e Planejamento Econômico 36(3), 525-550.

Silva, N. \& Andrade, J. P. d. (2007), 'Abordagem intertemporal da conta corrente: introduzindo câmbio e juros no modelo básico.', Revista de Economia Aplicada 11(2), 157-187.

Weber, C. (2002), 'Intertemporal non-separability and "rule of thumb" consumption', Journal of Monetary Economics, 49, 293-308. 
The Dynamics of the Brazilian Current Account with Rule of Thumb Consumers

\section{Appendix A Groups of Instruments}

Table A.1: Groups of instruments

\begin{tabular}{lccccc}
\hline Group & Instruments & Group & Instruments & Group & Instruments \\
\hline 1 & $\Delta Y_{t}, \Delta I_{t}$ & 9 & $\Delta I_{t}, \Delta I_{t-1}$ & 17 & $\Delta Y_{t}, \Delta I_{t}, \Delta G_{t}$ \\
2 & $\Delta Y_{t}, \Delta I_{t}, \Delta Y_{t-1}, \Delta I_{t-1}$ & 10 & $\Delta I_{t}, \Delta I_{t-1}, \Delta I_{t-2}$ & 18 & $\Delta Y_{t}, \Delta C_{t-1}$ \\
3 & $\Delta Y_{t}, \Delta Y_{t-1}$ & 11 & $\Delta Y_{t}, \Delta I_{t}, \Delta I_{t-1}$ & 19 & $\Delta I_{t}, \Delta C_{t-1}$ \\
4 & $\Delta Y_{t}, \Delta Y_{t-1}, \Delta Y_{t-2}$ & 12 & $\Delta Y_{t}, \Delta I_{t}, \Delta I_{t-1}, \Delta I_{t-2}$ & 20 & $\Delta Y_{t}, \Delta I_{t}, \Delta C_{t-1}$ \\
5 & $\Delta Y_{t}, \Delta Y_{t-1}, \Delta I_{t}$ & 13 & $\Delta Y_{t-1}, \Delta I_{t}$ & 21 & $\Delta Y_{t}, \Delta G_{t}, \Delta C_{t-1}$ \\
6 & $\Delta Y_{t}, \Delta Y_{t-1}, \Delta Y_{t-2}, \Delta I_{t}$ & 14 & $\Delta Y_{t-1}, \Delta Y_{t-2}, \Delta I_{t}$ & 22 & $\Delta I_{t}, \Delta G_{t}, \Delta C_{t-1}$ \\
7 & $\Delta Y_{t}, \Delta I_{t-1}$ & 15 & $\Delta Y_{t}, \Delta G_{t}$ & 23 & $\Delta Y_{t}, \Delta I_{t}, \Delta G_{t}, \Delta C_{t-1}$ \\
8 & $\Delta Y_{t}, \Delta I_{t-1}$ & 16 & $\Delta I_{t}, \Delta G_{t}$ & & \\
\hline
\end{tabular}


Appendix B Results of Estimation of the parameters $\phi$ 
Table B.1: Estimation of (13) at $2 \%$ interest rate

\begin{tabular}{|c|c|c|c|c|c|c|c|c|c|c|c|c|c|}
\hline \multirow[t]{2}{*}{ Group } & \multicolumn{3}{|c|}{ GMM - Newey-West Fixed } & \multicolumn{3}{|c|}{ GMM - Newey-West Variable } & \multicolumn{3}{|c|}{ GMM - Andrews } & \multicolumn{3}{|c|}{ 2SLS } & \multirow[t]{2}{*}{ Noobs. } \\
\hline & $(1-\lambda)$ & $\phi$ & J Stat. & $(1-\lambda)$ & $\phi$ & J Stat. & $(1-\lambda)$ & $\Phi$ & J Stat. & $(1-\lambda)$ & $\phi$ & J Stat. & \\
\hline 1 & $\begin{array}{c}0.3586^{* *} \\
(0.1605)\end{array}$ & $\begin{array}{c}-0.0723 \\
(0.1875)\end{array}$ & 0.0057 & $\begin{array}{c}0.3391^{* * *} \\
(0.1557)\end{array}$ & $\begin{array}{c}-0.0311 \\
(0.1662)\end{array}$ & 0.0085 & $\begin{array}{l}0.3587^{*} \\
(0.1911)\end{array}$ & $\begin{array}{c}-0.0668 \\
(0.2054)\end{array}$ & 0.0042 & $\begin{array}{c}0.3552^{* *} \\
(0.1621)\end{array}$ & $\begin{array}{c}-0.0570 \\
(0.1883)\end{array}$ & 0.6363 & 62 \\
\hline 2 & $\begin{array}{c}0.3542^{* *} \\
(0.1545)\end{array}$ & $\begin{array}{c}-0.0451 \\
(0.1771)\end{array}$ & 0.0312 & $\begin{array}{l}0.0312 \\
(0.1476)\end{array}$ & $\begin{array}{c}-0.0536 \\
(0.1754)\end{array}$ & 0.0360 & $\begin{array}{c}0.3658^{* *} \\
(0.1823)\end{array}$ & $\begin{array}{c}-0.0611 \\
(0.1988)\end{array}$ & 0.0301 & $\begin{array}{c}0.3837^{* *} \\
(0.1852)\end{array}$ & $\begin{array}{r}-0.0655 \\
(0.1990)\end{array}$ & 1.9655 & 61 \\
\hline 3 & $\begin{array}{l}0.2948 \\
(0.2046)\end{array}$ & $\begin{array}{c}-0.0709 \\
(0.1890)\end{array}$ & 0.0001 & $\begin{array}{l}0.2867^{*} \\
(0.1516)\end{array}$ & $\begin{array}{r}-0.0636 \\
(0.1900)\end{array}$ & 0.0003 & $\begin{array}{l}0.2910 \\
(0.2385)\end{array}$ & $\begin{array}{c}-0.0693 \\
(0.2079)\end{array}$ & 0.0001 & $\begin{array}{l}0.2859 \\
(0.2303)\end{array}$ & $\begin{array}{c}-0.0675 \\
(0.1951)\end{array}$ & 0.0095 & 61 \\
\hline 4 & $\begin{array}{l}0.2456 \\
(0.1727)\end{array}$ & $\begin{array}{c}-0.0249 \\
(0.1341)\end{array}$ & 0.0023 & $\begin{array}{l}0.2525^{*} \\
(0.1477)\end{array}$ & $\begin{array}{c}-0.0094 \\
(0.1151)\end{array}$ & 0.0034 & $\begin{array}{l}0.2510 \\
(0.2208)\end{array}$ & $\begin{array}{c}-0.0378 \\
(0.1852)\end{array}$ & 0.0021 & $\begin{array}{l}0.2558 \\
(0.1909)\end{array}$ & $\begin{array}{c}-0.0517 \\
(0.1644)\end{array}$ & 0.1254 & 60 \\
\hline 5 & $\begin{array}{c}0.3657^{* *} \\
(0.1567)\end{array}$ & $\begin{array}{c}-0.0751 \\
(0.1865)\end{array}$ & 0.0058 & $\begin{array}{c}0.3471^{* *} \\
(0.1539)\end{array}$ & $\begin{array}{c}-0.0325 \\
(0.1657)\end{array}$ & 0.0087 & $\begin{array}{l}0.3602^{*} \\
(0.1840)\end{array}$ & $\begin{array}{c}-0.0650 \\
(0.2003)\end{array}$ & 0.0044 & $\begin{array}{l}0.3467^{*} \\
(0.1786)\end{array}$ & $\begin{array}{c}-0.0505 \\
(0.1916)\end{array}$ & 0.6369 & 61 \\
\hline 6 & $\begin{array}{c}0.3187^{* * *} \\
(0.1439)\end{array}$ & $\begin{array}{l}0.0049 \\
(0.1260)\end{array}$ & 0.0138 & $\begin{array}{c}0.3268^{* *} \\
(0.1493)\end{array}$ & $\begin{array}{r}-0.0022 \\
(0.1336)\end{array}$ & 0.0120 & $\begin{array}{l}0.3292^{*} \\
(0.1781)\end{array}$ & $\begin{array}{r}-0.0127 \\
(0.1693)\end{array}$ & 0.0097 & $\begin{array}{l}0.3131^{*} \\
(0.1576)\end{array}$ & $\begin{array}{c}-0.0244 \\
(0.1547)\end{array}$ & 0.9094 & 60 \\
\hline 7 & $\begin{array}{l}0.3378^{*} \\
(0.1928)\end{array}$ & $\begin{array}{l}-0.0406 \\
(0.1778)\end{array}$ & 0.0224 & $\begin{array}{c}0.3946^{* *} \\
(0.1753)\end{array}$ & $\begin{array}{c}-0.0504 \\
(0.1758)\end{array}$ & 0.0314 & $\begin{array}{l}0.3392 \\
(0.2303)\end{array}$ & $\begin{array}{l}-0.0424 \\
(0.1999)\end{array}$ & 0.0222 & $\begin{array}{l}0.2622 \\
(0.2165)\end{array}$ & $\begin{array}{c}-0.0405 \\
(0.1868)\end{array}$ & 0.9863 & 61 \\
\hline 8 & $\begin{array}{c}0.4409^{* * * *} \\
(0.1225)\end{array}$ & $\begin{array}{c}-0.1197 \\
(0.1489)\end{array}$ & 0.0313 & $\begin{array}{c}0.3568^{* * * *} \\
(0.0810)\end{array}$ & $\begin{array}{r}-0.1008 \\
(0.1079)\end{array}$ & 0.0334 & $\begin{array}{c}0.4485^{* * * *} \\
(0.1411)\end{array}$ & $\begin{array}{c}-0.1100 \\
(0.1676)\end{array}$ & 0.0304 & $\begin{array}{c}0.3528^{* * *} \\
(0.1383)\end{array}$ & $\begin{array}{r}-0.1038 \\
(0.1487)\end{array}$ & 1.4227 & 60 \\
\hline 9 & $\begin{array}{l}0.3084 \\
(0.2505)\end{array}$ & $\begin{array}{l}0.0201 \\
(0.4288)\end{array}$ & 0.0208 & $\begin{array}{l}0.5028^{*} \\
(0.2526)\end{array}$ & $\begin{array}{c}-0.3205 \\
(0.3743)\end{array}$ & 0.0228 & $\begin{array}{l}0.2908 \\
(0.3164)\end{array}$ & $\begin{array}{l}0.0522 \\
(0.5505)\end{array}$ & 0.0206 & $\begin{array}{l}0.4216 \\
(0.2859)\end{array}$ & $\begin{array}{c}-0.2477 \\
(0.5236)\end{array}$ & 1.1077 & 61 \\
\hline 10 & $\begin{array}{c}0.4360^{* *} \\
(0.1740)\end{array}$ & $\begin{array}{c}-0.1956 \\
(0.3358)\end{array}$ & 0.0330 & $\begin{array}{c}0.4068^{* * *} \\
(0.0848)\end{array}$ & $\begin{array}{c}-0.1739 \\
(0.1371)\end{array}$ & 0.0278 & $\begin{array}{c}0.4614^{* *} \\
(0.2005)\end{array}$ & $\begin{array}{c}-0.2402 \\
(0.4016)\end{array}$ & 0.0358 & $\begin{array}{c}0.4629^{* *} \\
(0.1871)\end{array}$ & $\begin{array}{c}-0.3128 \\
(0.3818)\end{array}$ & 1.0585 & 60 \\
\hline 11 & $\begin{array}{c}0.3374^{* *} \\
(0.1587)\end{array}$ & $\begin{array}{c}-0.0405 \\
(0.1772)\end{array}$ & 0.0224 & $\begin{array}{c}0.4076^{* * * *} \\
(0.1520)\end{array}$ & $\begin{array}{c}-0.0617 \\
(0.1784)\end{array}$ & 0.0366 & $\begin{array}{l}0.3373^{*} \\
(0.1908)\end{array}$ & $\begin{array}{c}-0.0423 \\
(0.2001)\end{array}$ & 0.0222 & $\begin{array}{l}0.3195^{*} \\
(0.1650)\end{array}$ & $\begin{array}{c}-0.0307 \\
(0.1816)\end{array}$ & 1.4702 & 61 \\
\hline 12 & $\begin{array}{c}0.3374^{* *} \\
(0.1587)\end{array}$ & $\begin{array}{c}-0.0405 \\
(0.1772)\end{array}$ & 0.0224 & $\begin{array}{c}0.4076^{* * * *} \\
(0.1520)\end{array}$ & $\begin{array}{c}-0.0617 \\
(0.1784)\end{array}$ & 0.0366 & $\begin{array}{l}0.3373^{*} \\
(0.1908)\end{array}$ & $\begin{array}{c}-0.0423 \\
(0.2001)\end{array}$ & 0.0222 & $\begin{array}{l}0.3195^{*} \\
(0.1650)\end{array}$ & $\begin{array}{c}-0.0307 \\
(0.1816)\end{array}$ & 1.4702 & 61 \\
\hline 13 & $\begin{array}{l}0.5167 \\
(0.3296)\end{array}$ & $\begin{array}{c}-0.3810 \\
(0.5887)\end{array}$ & 0.0002 & $\begin{array}{l}0.5191^{*} \\
(0.3091)\end{array}$ & $\begin{array}{r}-0.3832 \\
(0.4758)\end{array}$ & 0.0008 & $\begin{array}{c}0.5152 \\
(0.3390)\end{array}$ & $\begin{array}{c}-0.3771 \\
(0.6128)\end{array}$ & 0.0002 & $\begin{array}{l}0.5231 \\
(0.3402)\end{array}$ & $\begin{array}{r}-0.3786 \\
(0.5983)\end{array}$ & 0.0077 & 61 \\
\hline 14 & $\begin{array}{l}0.3866 \\
(0.2632)\end{array}$ & $\begin{array}{c}-0.1465 \\
(0.4797)\end{array}$ & 0.0114 & $\begin{array}{l}0.3557^{*} \\
(0.1839)\end{array}$ & $\begin{array}{c}-0.1300 \\
(0.2797)\end{array}$ & 0.0095 & $\begin{array}{l}0.3669 \\
(0.2987)\end{array}$ & $\begin{array}{c}-0.0894 \\
(0.5183)\end{array}$ & 0.0101 & $\begin{array}{l}0.4140 \\
(0.2703)\end{array}$ & $\begin{array}{c}-0.2257 \\
(0.5014)\end{array}$ & 0.5962 & 60 \\
\hline 15 & $\begin{array}{c}0.4995^{* * * *} \\
(0.1591)\end{array}$ & $\begin{array}{c}-0.2076 \\
(0.2099)\end{array}$ & $0.0454^{*}$ & $\begin{array}{c}0.8642^{* * * *} \\
(0.1666)\end{array}$ & $\begin{array}{c}-0.8835^{* * *} \\
(0.2576)\end{array}$ & 0.0324 & $\begin{array}{c}0.4891^{* * * *} \\
(0.1718)\end{array}$ & $\begin{array}{c}-0.1409 \\
(0.2100)\end{array}$ & 0.0343 & $\begin{array}{c}0.4379^{* *} \\
(0.1647)\end{array}$ & $\begin{array}{r}-0.1627 \\
(0.2030)\end{array}$ & $3.6334^{*}$ & 62 \\
\hline 16 & $\begin{array}{c}0.9014^{* *} \\
(0.3794)\end{array}$ & $\begin{array}{c}-1.0062^{*} \\
(0.5677)\end{array}$ & 0.0183 & $\begin{array}{c}1.0107^{* * * *} \\
(0.2391)\end{array}$ & $\begin{array}{c}-1.0953^{* * *} \\
(0.3462)\end{array}$ & 0.0146 & $\begin{array}{c}0.9574^{* * *} \\
(0.3622)\end{array}$ & $\begin{array}{c}-1.0647^{*} \\
(0.5378)\end{array}$ & 0.0175 & $\begin{array}{c}0.7237^{* * *} \\
(0.3466)\end{array}$ & $\begin{array}{c}-0.6948 \\
(0.5736)\end{array}$ & 0.7868 & 62 \\
\hline 17 & $\begin{array}{c}0.4781^{* * *} \\
(0.1581)\end{array}$ & $\begin{array}{c}-0.2498 \\
(0.2155)\end{array}$ & 0.0476 & $\begin{array}{c}0.4362^{* * * *} \\
(0.1359)\end{array}$ & $\begin{array}{c}-0.1413 \\
(0.1693)\end{array}$ & 0.0355 & $\begin{array}{c}0.4506^{* * *} \\
(0.1703)\end{array}$ & $\begin{array}{c}-0.1919 \\
(0.2114)\end{array}$ & 0.0416 & $\begin{array}{c}0.5037^{* * *} \\
(0.1448)\end{array}$ & $\begin{array}{r}-0.1478 \\
(0.1978)\end{array}$ & 4.3250 & 62 \\
\hline 18 & $\begin{array}{l}0.3480^{*} \\
(0.1783)\end{array}$ & $\begin{array}{l}-0.1036 \\
(0.1888)\end{array}$ & 0.0051 & $\begin{array}{c}0.3820^{* * * *} \\
(0.1333)\end{array}$ & $\begin{array}{c}-0.1750 \\
(0.1935)\end{array}$ & 0.0087 & $\begin{array}{l}0.3689^{*} \\
(0.1978)\end{array}$ & $\begin{array}{c}-0.1049 \\
(0.2064)\end{array}$ & 0.0054 & $\begin{array}{l}0.3962^{*} \\
(0.2041)\end{array}$ & $\begin{array}{l}-0.1303 \\
(0.2051)\end{array}$ & 0.5148 & 61 \\
\hline 19 & $\begin{array}{l}0.5031 \\
(0.3226)\end{array}$ & $\begin{array}{c}-0.3428 \\
(0.5766)\end{array}$ & 0.0049 & $\begin{array}{l}0.5609^{*} \\
(0.3077)\end{array}$ & $\begin{array}{c}-0.4347 \\
(0.4784)\end{array}$ & 0.0071 & $\begin{array}{l}0.4862 \\
(0.3359)\end{array}$ & $\begin{array}{c}-0.3028 \\
(0.6088)\end{array}$ & 0.0048 & $\begin{array}{l}0.6009 \\
(0.3834)\end{array}$ & $\begin{array}{l}-0.4344 \\
(0.6243)\end{array}$ & 0.3243 & 61 \\
\hline 20 & $\begin{array}{c}0.3906^{* * *} \\
(0.1470)\end{array}$ & $\begin{array}{c}-0.0991 \\
(0.1859)\end{array}$ & 0.0091 & $\begin{array}{c}0.3793^{* * *} \\
(0.1429)\end{array}$ & $\begin{array}{c}-0.0536 \\
(0.1686)\end{array}$ & 0.0140 & $\begin{array}{c}0.3925^{* * *} \\
(0.1737)\end{array}$ & $\begin{array}{c}-0.0941 \\
(0.1989)\end{array}$ & 0.0070 & $\begin{array}{c}0.4422^{* * *} \\
(0.1749)\end{array}$ & $\begin{array}{c}-0.1102 \\
(0.1992)\end{array}$ & 1.0279 & 61 \\
\hline 21 & $\begin{array}{c}0.5354^{* * * *} \\
(0.1562)\end{array}$ & $\begin{array}{c}-0.2428 \\
(0.2161)\end{array}$ & 0.0523 & $\begin{array}{c}0.7690^{* * * *} \\
(0.1245)\end{array}$ & $\begin{array}{c}-0.7350^{* * *} \\
(0.2055)\end{array}$ & 0.0366 & $\begin{array}{c}0.4888^{* * *} \\
(0.1706)\end{array}$ & $\begin{array}{c}-0.1345 \\
(0.2071)\end{array}$ & 0.0366 & $\begin{array}{c}0.4672^{* * *} \\
(0.2063)\end{array}$ & $\begin{array}{c}-0.1776 \\
(0.2179)\end{array}$ & 3.5926 & 61 \\
\hline 22 & $\begin{array}{c}0.8289^{* * *} \\
(0.3253)\end{array}$ & $\begin{array}{c}-0.9192^{*} \\
(0.5168)\end{array}$ & 0.0236 & $\begin{array}{c}1.0070^{* * * *} \\
(0.2367)\end{array}$ & $\begin{array}{c}-1.0971^{* * * *} \\
(0.3459)\end{array}$ & 0.0296 & $\begin{array}{c}0.8672^{* * * *} \\
(0.3159)\end{array}$ & $\begin{array}{c}-0.9649^{*} \\
(0.4977)\end{array}$ & 0.0246 & $\begin{array}{l}0.7578^{*} \\
(0.3920)\end{array}$ & $\begin{array}{c}-0.7012 \\
(0.5793)\end{array}$ & 0.8440 & 61 \\
\hline 23 & $\begin{array}{c}0.5742^{* * * *} \\
(0.1730)\end{array}$ & $\begin{array}{c}-0.4287^{*} \\
(0.2340)\end{array}$ & 0.0578 & $\begin{array}{c}0.4370^{* * * *} \\
(0.1316)\end{array}$ & $\begin{array}{r}-0.1928 \\
(0.1510)\end{array}$ & 0.0302 & $\begin{array}{c}0.4507^{* *} \\
(0.1707)\end{array}$ & $\begin{array}{c}-0.2086 \\
(0.2140)\end{array}$ & 0.0491 & $\begin{array}{c}0.5199^{* * *} \\
(0.1795)\end{array}$ & $\begin{array}{c}-0.1562 \\
(0.2109)\end{array}$ & 4.2180 & 61 \\
\hline
\end{tabular}

Note: $1 \%, 5 \%$ and $10 \%$ significance are represented by ${ }^{* * *},{ }^{* *}$ and ${ }^{*}$, respectively. The values in parentheses correspond to standard deviation. 
Table B.2: Estimation of (13) at $4 \%$ interest rate

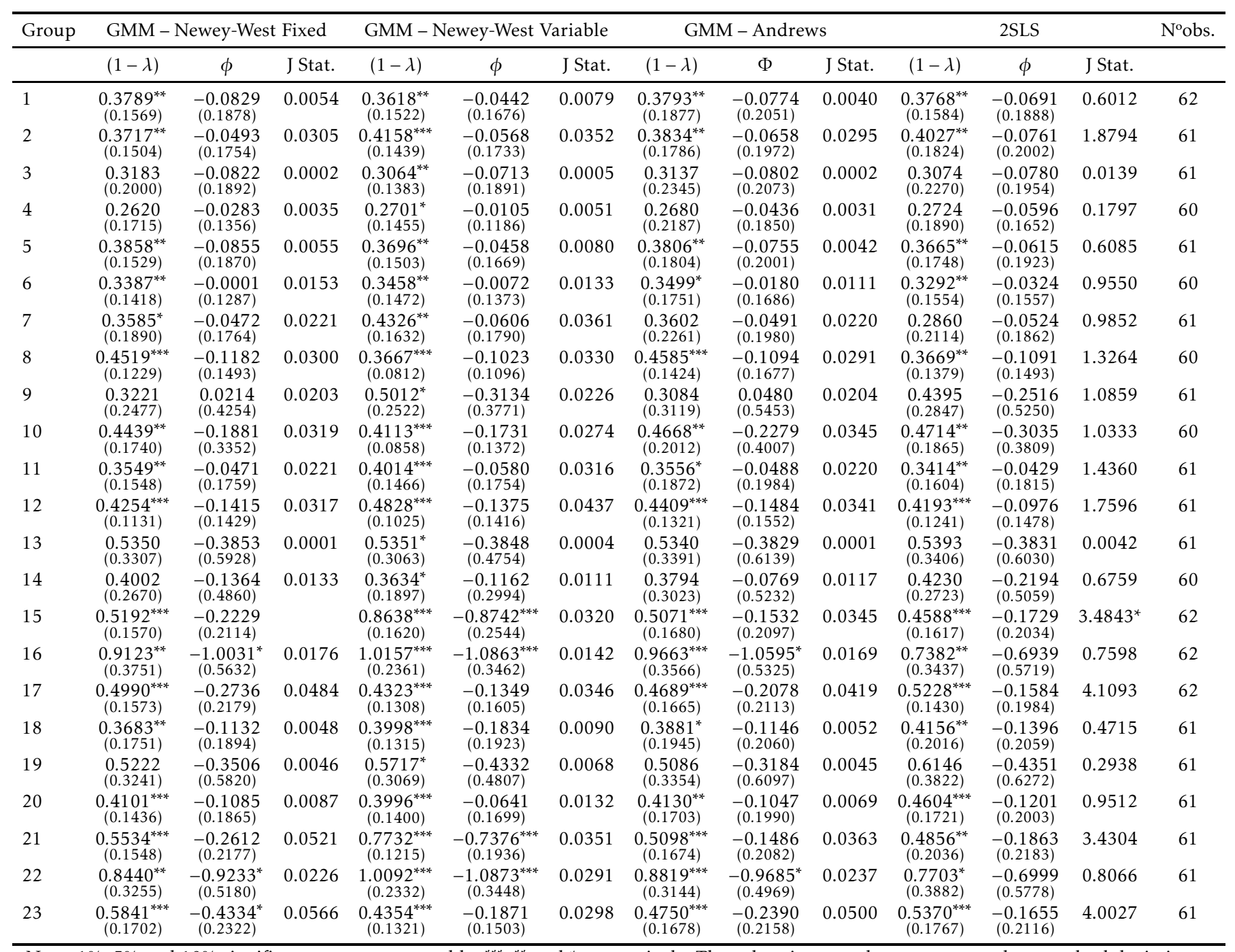


Table B.3: Estimation of (13) at $8 \%$ interest rate

\begin{tabular}{|c|c|c|c|c|c|c|c|c|c|c|c|c|c|}
\hline \multirow[t]{2}{*}{ Group } & \multicolumn{3}{|c|}{ GMM - Newey-West Fixed } & \multicolumn{3}{|c|}{ GMM - Newey-West Variable } & \multicolumn{3}{|c|}{ GMM - Andrews } & \multicolumn{3}{|c|}{ 2SLS } & \multirow[t]{2}{*}{$\mathrm{N}^{\circ}$ obs. } \\
\hline & $(1-\lambda)$ & $\phi$ & J Stat. & $(1-\lambda)$ & $\phi$ & J Stat. & $(1-\lambda)$ & $\Phi$ & J Stat. & $(1-\lambda)$ & $\phi$ & J Stat. & \\
\hline 1 & $\begin{array}{c}0.4200^{* * *} \\
(0.1511)\end{array}$ & $\begin{array}{c}-0.1045 \\
(0.1893)\end{array}$ & 0.0047 & $\begin{array}{c}0.4078^{* * *} \\
(0.1468)\end{array}$ & $\begin{array}{c}-0.0708 \\
(0.1711)\end{array}$ & 0.0068 & $\begin{array}{r}0.4205^{* *} \\
(0.1818)\end{array}$ & $\begin{array}{r}-0.0987 \\
(0.2050)\end{array}$ & 0.0036 & $\begin{array}{c}0.4199^{* * *} \\
(0.1525)\end{array}$ & $\begin{array}{c}-0.0932 \\
(0.1907)\end{array}$ & 0.5285 & 62 \\
\hline 2 & $\begin{array}{c}0.4072^{* * *} \\
(0.1432)\end{array}$ & $\begin{array}{r}-0.0584 \\
(0.1722)\end{array}$ & 0.0289 & $\begin{array}{c}0.4292^{* * * *} \\
(0.1339)\end{array}$ & $\begin{array}{r}-0.0486 \\
(0.1616)\end{array}$ & 0.0332 & $\begin{array}{r}0.4186^{* *} \\
(0.1719)\end{array}$ & $\begin{array}{r}-0.0759 \\
(0.1943)\end{array}$ & 0.0281 & $\begin{array}{r}0.4408^{* *} \\
(0.1773)\end{array}$ & $\begin{array}{c}-0.0975 \\
(0.2029)\end{array}$ & 1.7015 & 61 \\
\hline 3 & $\begin{array}{c}0.3654^{*} \\
(0.1922)\end{array}$ & $\begin{array}{r}-0.1050 \\
(0.1904)\end{array}$ & 0.0004 & $\begin{array}{c}0.3506^{* *} \\
(0.1334)\end{array}$ & $\begin{array}{r}-0.0922 \\
(0.1916)\end{array}$ & 0.0010 & $\begin{array}{c}0.3598 \\
(0.2256)\end{array}$ & $\begin{array}{r}-0.1021 \\
(0.2061)\end{array}$ & 0.0003 & $\begin{array}{c}0.3502 \\
(0.2214)\end{array}$ & $\begin{array}{c}-0.0991 \\
(0.1966)\end{array}$ & & 61 \\
\hline 4 & $\begin{array}{c}0.2960 * \\
(0.1698)\end{array}$ & $\begin{array}{r}-0.0364 \\
(0.1394)\end{array}$ & 0.0065 & $\begin{array}{c}0.3091^{* * *} \\
(0.1516)\end{array}$ & $\begin{array}{r}-0.0215 \\
(0.1333)\end{array}$ & 0.0103 & $\begin{array}{c}0.3039 \\
(0.2150)\end{array}$ & $\begin{array}{c}-0.0563 \\
(0.1849)\end{array}$ & 0.0058 & $\begin{array}{c}0.3057 \\
(0.1858)\end{array}$ & $\begin{array}{r}-0.0752 \\
(0.1672)\end{array}$ & 0.3167 & 60 \\
\hline 5 & $\begin{array}{c}0.4263^{* * * *} \\
(0.1465)\end{array}$ & $\begin{array}{c}-0.1065 \\
(0.1885)\end{array}$ & 0.0048 & $\begin{array}{c}0.4148^{* * * * *} \\
(0.1449)\end{array}$ & $\begin{array}{c}-0.0732 \\
(0.1703)\end{array}$ & 0.0068 & $\begin{array}{r}0.4213^{* *} \\
(0.1739)\end{array}$ & $\begin{array}{c}-0.0964 \\
(0.2002)\end{array}$ & 0.0038 & $\begin{array}{r}0.4060^{* *} \\
(0.1680)\end{array}$ & $\begin{array}{c}-0.0835 \\
(0.1943)\end{array}$ & 0.5516 & 61 \\
\hline 6 & $\begin{array}{c}0.3808^{* * * *} \\
(0.1378)\end{array}$ & $\begin{array}{r}-0.0130 \\
(0.1352)\end{array}$ & 0.0190 & $\begin{array}{c}0.3965^{* * * *} \\
(0.1368)\end{array}$ & $\begin{array}{r}-0.0319 \\
(0.1432)\end{array}$ & 0.0182 & $\begin{array}{r}0.3932^{\text {*** }} \\
(0.1691)\end{array}$ & $\begin{array}{r}-0.0299 \\
(0.1677)\end{array}$ & 0.0144 & $\begin{array}{r}0.3615^{* * *} \\
(0.1516)\end{array}$ & $\begin{array}{r}-0.0486 \\
(0.1583)\end{array}$ & 1.0693 & 60 \\
\hline 7 & $\begin{array}{c}0.3991^{* *} \\
(0.1835)\end{array}$ & $\begin{array}{c}-0.0604 \\
(0.1741)\end{array}$ & 0.0215 & $\begin{array}{c}0.4390^{* * *} \\
(0.1752)\end{array}$ & $\begin{array}{c}-0.0709 \\
(0.1722)\end{array}$ & 0.0302 & $\begin{array}{c}0.4017^{*} \\
(0.2188)\end{array}$ & $\begin{array}{r}-0.0626 \\
(0.1947)\end{array}$ & 0.0215 & $\begin{array}{c}0.3334 \\
(0.2027)\end{array}$ & $\begin{array}{c}-0.0761 \\
(0.1857)\end{array}$ & 0.9718 & 61 \\
\hline 8 & $\begin{array}{c}0.4738^{* * * *} \\
(0.1257)\end{array}$ & $\begin{array}{r}-0.1154 \\
(0.1503)\end{array}$ & 0.0273 & $\begin{array}{c}0.4059^{* * * *} \\
(0.0910)\end{array}$ & $\begin{array}{r}-0.1126 \\
(0.1150)\end{array}$ & 0.0330 & $\begin{array}{c}0.4772^{* * * *} \\
(0.1465)\end{array}$ & $\begin{array}{r}-0.1085 \\
(0.1679)\end{array}$ & 0.0264 & $\begin{array}{c}0.3949^{* * * *} \\
(0.1387)\end{array}$ & $\begin{array}{r}-0.1196 \\
(0.1510)\end{array}$ & 1.1545 & 60 \\
\hline 9 & $\begin{array}{c}0.3502 \\
(0.2427)\end{array}$ & $\begin{array}{l}0.0233 \\
(0.4192)\end{array}$ & 0.0193 & $\begin{array}{r}0.5108^{* *} \\
(0.2347)\end{array}$ & $\begin{array}{c}-0.3148 \\
(0.3540)\end{array}$ & 0.0211 & $\begin{array}{c}0.3441 \\
(0.3034)\end{array}$ & $\begin{array}{l}0.0386 \\
(0.5359)\end{array}$ & 0.0199 & $\begin{array}{c}0.4754^{*} \\
(0.2833)\end{array}$ & $\begin{array}{r}-0.2594 \\
(0.5289)\end{array}$ & 1.0355 & 61 \\
\hline 10 & $\begin{array}{c}0.4588^{* *} \\
(0.1744)\end{array}$ & $\begin{array}{c}-0.1703 \\
(0.3347)\end{array}$ & 0.0296 & $\begin{array}{c}0.4241^{* * * *} \\
(0.0878)\end{array}$ & $\begin{array}{c}-0.1754 \\
(0.1378)\end{array}$ & 0.0265 & $\begin{array}{r}0.4761^{* *} \\
(0.2040)\end{array}$ & $\begin{array}{r}-0.1974 \\
(0.4015)\end{array}$ & 0.0313 & $\begin{array}{r}0.4886^{* *} \\
(0.1860)\end{array}$ & $\begin{array}{r}-0.2847 \\
(0.3799)\end{array}$ & 0.9873 & 60 \\
\hline 11 & $\begin{array}{r}0.3895^{* *} \\
(0.1483)\end{array}$ & $\begin{array}{c}-0.0598 \\
(0.1736)\end{array}$ & 0.0215 & $\begin{array}{c}0.4293^{* * * *} \\
(0.1440)\end{array}$ & $\begin{array}{c}-0.0710 \\
(0.1717)\end{array}$ & 0.0303 & $\begin{array}{r}0.3919^{* *} \\
(0.1807)\end{array}$ & $\begin{array}{r}-0.0620 \\
(0.1953)\end{array}$ & 0.0215 & $\begin{array}{c}0.3851^{* *} \\
(0.1525)\end{array}$ & $\begin{array}{c}-0.0673 \\
(0.1819)\end{array}$ & 1.3552 & 61 \\
\hline 12 & $\begin{array}{c}0.4458^{* * * *} \\
(0.1131)\end{array}$ & $\begin{array}{c}-0.1372 \\
(0.1450)\end{array}$ & 0.0294 & $\begin{array}{c}0.4948^{* * * *} \\
(0.1025)\end{array}$ & $\begin{array}{r}-0.1492 \\
(0.1440)\end{array}$ & 0.0389 & $\begin{array}{c}0.4578^{* * *} \\
(0.1346)\end{array}$ & $\begin{array}{r}-0.1407 \\
(0.1572)\end{array}$ & 0.0307 & $\begin{array}{c}0.4441^{* * * *} \\
(0.1252)\end{array}$ & $\begin{array}{c}-0.1089 \\
(0.1498)\end{array}$ & 1.5208 & 60 \\
\hline 13 & $\begin{array}{c}0.5708^{*} \\
(0.3333)\end{array}$ & $\begin{array}{c}-0.3929 \\
(0.6017)\end{array}$ & 0.0000 & $\begin{array}{c}0.5698^{*} \\
(0.3011)\end{array}$ & $\begin{array}{c}-0.3911 \\
(0.4731)\end{array}$ & 0.0000 & $\begin{array}{c}0.5706^{*} \\
(0.3406)\end{array}$ & $\begin{array}{r}-0.3923 \\
(0.6191)\end{array}$ & 0.0000 & $\begin{array}{c}0.5718^{*} \\
(0.3420)\end{array}$ & $\begin{array}{r}-0.3919 \\
(0.6133)\end{array}$ & 0.0004 & 61 \\
\hline 14 & $\begin{array}{c}0.4294 \\
(0.2740)\end{array}$ & $\begin{array}{c}-0.1198 \\
(0.4999)\end{array}$ & 0.0173 & $\begin{array}{c}0.3962^{*} \\
(0.2191)\end{array}$ & $\begin{array}{r}-0.1034 \\
(0.3731)\end{array}$ & 0.0154 & $\begin{array}{c}0.4065 \\
(0.3077)\end{array}$ & $\begin{array}{r}-0.0555 \\
(0.5318)\end{array}$ & 0.0149 & $\begin{array}{c}0.4408 \\
(0.2769)\end{array}$ & $\begin{array}{c}-0.2067 \\
(0.5155)\end{array}$ & 0.8521 & 60 \\
\hline 15 & $\begin{array}{c}0.5581^{* * * *} \\
(0.1547)\end{array}$ & $\begin{array}{r}-0.2550 \\
(0.2152)\end{array}$ & $0.0467^{*}$ & $\begin{array}{c}0.8644^{* * * *} \\
(0.1544)\end{array}$ & $\begin{array}{c}-0.8562^{* * *} \\
(0.2485)\end{array}$ & 0.0312 & $\begin{array}{c}0.5432^{* * * *} \\
(0.1627)\end{array}$ & $\begin{array}{c}-0.1784 \\
(0.2104)\end{array}$ & 0.0349 & $\begin{array}{c}0.5007^{* * * *} \\
(0.1575)\end{array}$ & $\begin{array}{c}-0.1931 \\
(0.2048)\end{array}$ & $3.1690^{*}$ & 62 \\
\hline 16 & $\begin{array}{r}0.9335^{* *} \\
(0.3672)\end{array}$ & $\begin{array}{r}-0.9961^{*} \\
(0.5547)\end{array}$ & 0.0161 & $\begin{array}{c}1.0260^{* * * *} \\
(0.2311)\end{array}$ & $\begin{array}{c}-1.0683^{* * *} \\
(0.3467)\end{array}$ & 0.0134 & $\begin{array}{c}0.9829^{* * * *} \\
(0.3467)\end{array}$ & $\begin{array}{c}-1.0476^{* *} \\
(0.5232)\end{array}$ & 0.0157 & $\begin{array}{r}0.7672^{* *} \\
(0.3387)\end{array}$ & $\begin{array}{c}-0.6920 \\
(0.5695)\end{array}$ & 0.7054 & 62 \\
\hline 17 & $\begin{array}{c}0.5410^{* * * * *} \\
(0.1573)\end{array}$ & $\begin{array}{c}-0.3224 \\
(0.2229)\end{array}$ & 0.0493 & $\begin{array}{c}0.4639^{* * * *} \\
(0.1316)\end{array}$ & $\begin{array}{r}-0.1624 \\
(0.1610)\end{array}$ & 0.0349 & $\begin{array}{c}0.5060^{* * * *} \\
(0.1610)\end{array}$ & $\begin{array}{c}-0.2407 \\
(0.2125)\end{array}$ & 0.0422 & $\begin{array}{c}0.5611^{* * * *} \\
(0.1411)\end{array}$ & $\begin{array}{c}-0.1795 \\
(0.2001)\end{array}$ & 3.6727 & 62 \\
\hline 18 & $\begin{array}{c}0.4094^{* * *} \\
(0.1699)\end{array}$ & $\begin{array}{c}-0.1328 \\
(0.1911)\end{array}$ & 0.0043 & $\begin{array}{c}0.4248^{* * * *} \\
(0.1387)\end{array}$ & $\begin{array}{c}-0.1895 \\
(0.2010)\end{array}$ & 0.0082 & $\begin{array}{c}0.4250^{* * *} \\
(0.1882)\end{array}$ & $\begin{array}{r}-0.1329 \\
(0.2053)\end{array}$ & 0.0046 & $\begin{array}{r}0.4545^{* *} \\
(0.1977)\end{array}$ & $\begin{array}{c}-0.1583 \\
(0.2081)\end{array}$ & 0.3877 & 61 \\
\hline 19 & $\begin{array}{c}0.5608^{*} \\
(0.3280)\end{array}$ & $\begin{array}{c}-0.3661 \\
(0.5936)\end{array}$ & 0.0039 & $\begin{array}{c}0.5968^{*} \\
(0.3042)\end{array}$ & $\begin{array}{c}-0.4365 \\
(0.4795)\end{array}$ & 0.0065 & $\begin{array}{c}0.5518 \\
(0.3368)\end{array}$ & $\begin{array}{r}-0.3443 \\
(0.6154)\end{array}$ & 0.0039 & $\begin{array}{c}0.6420^{*} \\
(0.3802)\end{array}$ & $\begin{array}{c}-0.4365 \\
(0.6338)\end{array}$ & 0.2373 & 61 \\
\hline 20 & $\begin{array}{c}0.4498^{* * * *} \\
(0.1379)\end{array}$ & $\begin{array}{r}-0.1276 \\
(0.1885)\end{array}$ & 0.0079 & $\begin{array}{c}0.4526^{* * * *} \\
(0.1390)\end{array}$ & $\begin{array}{c}-0.1079 \\
(0.1785)\end{array}$ & 0.0107 & $\begin{array}{c}0.4526^{* * *} \\
(0.1637)\end{array}$ & $\begin{array}{r}-0.1242 \\
(0.1991)\end{array}$ & 0.0064 & $\begin{array}{c}0.4967^{* * * *} \\
(0.1674)\end{array}$ & $\begin{array}{c}-0.1398 \\
(0.2031)\end{array}$ & 0.8019 & 61 \\
\hline 21 & $\begin{array}{c}0.5864^{* * *} \\
(0.1539)\end{array}$ & $\begin{array}{r}-0.2938 \\
(0.2204)\end{array}$ & 0.0513 & $\begin{array}{c}0.7830^{* * * *} \\
(0.1221)\end{array}$ & $\begin{array}{c}-0.7374^{* * *} \\
(0.1932)\end{array}$ & 0.0345 & $\begin{array}{c}0.5476^{* * *} \\
(0.1622)\end{array}$ & $\begin{array}{c}-0.1783 \\
(0.2098)\end{array}$ & 0.0372 & $\begin{array}{c}0.5226^{* *} \\
(0.1992)\end{array}$ & $\begin{array}{c}-0.2037 \\
(0.2196)\end{array}$ & 3.0994 & 61 \\
\hline 22 & $\begin{array}{c}0.8750^{* * * *} \\
(0.3268)\end{array}$ & $\begin{array}{r}-0.9309^{*} \\
(0.5204)\end{array}$ & 0.0205 & $\begin{array}{c}1.0163^{* * * *} \\
(0.2279)\end{array}$ & $\begin{array}{c}-1.0698^{* * *} \\
(0.3441)\end{array}$ & 0.0281 & $\begin{array}{c}0.9109^{* * *} \\
(0.3125)\end{array}$ & $\begin{array}{r}-0.9739^{*} \\
(0.4959)\end{array}$ & 0.0219 & $\begin{array}{c}0.7952^{* *} \\
(0.3811)\end{array}$ & $\begin{array}{r}-0.6971 \\
(0.5757)\end{array}$ & 0.7346 & 61 \\
\hline 23 & $\begin{array}{c}0.6030^{* * * *} \\
(0.1659)\end{array}$ & $\begin{array}{r}-0.4400^{*} \\
(0.2293)\end{array}$ & 0.0541 & $\begin{array}{c}0.4430^{* * * *} \\
(0.1335)\end{array}$ & $\begin{array}{r}-0.1919 \\
(0.1492)\end{array}$ & 0.0289 & $\begin{array}{c}0.5532^{* * * *} \\
(0.1646)\end{array}$ & $\begin{array}{c}-0.3512 \\
(0.2239)\end{array}$ & 0.0525 & $\begin{array}{c}0.5712^{* * * * *} \\
(0.1719)\end{array}$ & $\begin{array}{r}-0.1839 \\
(0.2134)\end{array}$ & 3.5742 & 61 \\
\hline
\end{tabular}

